\title{
Potencial de uso e condições de cultivo de Stenachaenium megapotamicum - uma planta ornamental
}

\author{
MARIANA GRASSI NOYA ${ }^{(2)}$ E FRANCINE LORENA CUQUEL ${ }^{(3)}$
}

\begin{abstract}
RESUMO
O mercado de plantas ornamentais busca por inovação e variedades bem adaptadas, porém a maioria das plantas ornamentais cultivadas no Brasil é exótica, as quais nem sempre são bem adaptadas. Stenachaenium megapotamicum é um subarbusto com alto potencial ornamental e ocorrência espontânea nos Campos Sulinos. Nesta pesquisa, avaliou-se o potencial paisagístico, potencial como flor de corte e adaptabilidade em diferentes condições de cultivo. A pesquisa foi conduzida entre os meses de junho de 2010 e maio de 2011, no município de Pinhais - PR. O potencial de uso paisagístico foi verificado por meio do crescimento em altura, diâmetro, número de hastes secundárias, número de folhas das plantas e suas características fenológicas. Para avaliação de seu potencial como flor de corte, foi realizado monitoramento das hastes florais em vasos contendo água durante oito dias. A adaptabilidade foi conduzida em quatro condições de cultivo: pleno sol com irrigação diária, pleno sol sem irrigação, casa de vegetação e sob tela sombreadora $(70 \%)$. As plantas apresentaram melhor adaptabilidade quando cultivadas a pleno sol com irrigação diária. Elas apresentam potencial para uso como flor de corte e em paisagismo, não sendo indicadas como planta envasada, por causa do porte elevado.
\end{abstract}

Palavras-chave: flor de corte, planta nativa, paisagismo, adaptabilidade.

\section{ABSTRACT \\ Use and growing conditions of Stenachaenium megapotamicum as ornamental plant}

\begin{abstract}
Ornamental plant market seeks innovation and well-adapted varieties; however, most ornamental plants grown in Brazil are exotic. These plants are not always ecologically well-adapted. Stenachaenium megapotamicum is a subshrub with ornamental potential, which grows spontaneously in the southern grasslands of Brazil. In this study, conducted from June 2010 to May 2011, Stenachaenium megapotamicum was evaluated in relation to landscaping use and cut flower potential, as well adaptability under different growing conditions. Potential for landscaping use was verified by means of its growth in height, diameter, number of secondary stems, number of leaves, and its phenological features. Flower stems were monitored for vase life during eight days for assessment of potential as a cut flower. Adaptability was assessed under four growing conditions: full sun with daily irrigation, full sun without irrigation, in a greenhouse and under a shade screen (70\%). They showed potential for use as a cut flower as well for landscaping, not being recommended as potted plants due to their excessive height. Plants showed greater adaptability when grown in full sun with daily irrigation.
\end{abstract}

Kaywords: cut flower, native plant, landscaping, vase life.

\section{INTRODUCTION}

Various native plants with ornamental potential have been the object of international research, manifesting the trend of searching for new species for landscaping as potted plants and as cut flowers (CARDOSO, 2010). Recently, studies in Brazil have sought to discover and value national flora for this same purpose. Preservation and introduction of native ornamental species in urban gardens are of great importance since they contribute to ecological landscaping, making maintenance of germplasm banks viable, providing food and habitat for native fauna, as well as reducing the biodiversity loss in these environments. Insertion of native flora species in floriculture is advantageous since these plants do not require a great deal of maintenance, are hardy and easily grown. These aspects make for profitable production, as well as increasing product offer.

National floriculture market has always been influenced by what is in fashion, and it is strongly influenced by European and American trends (HEIDEN et al., 2006), impeding the insertion of unknown native plants and undomesticated plants. Only in the 1960s did the use of native tropical plants from Brazil come about worldwide, through the initiative of Burle Marx (BARROSO et al., 2007), allowing Brazilian flora to acquire international insertion (OTTMANN et al., 2008). Nevertheless, this isolated initiative of use of tropical plants was not accompanied by insertion of the native subtropical and temperate plants in landscaping. This probably occurred because the production of native ornamental plants runs up against a lack of knowledge of potential plants, their best use, and production and management techniques, such as light requirements (ZANELLA et al., 2006), water demand (SOUZA et al., 2010) and development in the soil as compared to growth in packaging.

The focus of this study was Stenachaenium megapotamicum (Spreng.) Baker, a subshrub with significant ornamental potential, which spontaneously grows in fields and secondary vegetation of Brazilian southern grasslands (STUMPF et al., 2009). During the research it was evaluated its potential for use as landscaping plant and as cut flower, and its adaptability under different growing conditions.

\footnotetext{
${ }^{(1)}$ Recebido em 10 de maio de 2013 e aceito para publicação em 30 junho de 2013.

(2) contato@marianagrassi.com, (3) francine@ufpr.br
} 


\section{MATERIAL AND METHODS}

Study was conducted from June 2010 to May 2011 in Brazil at $25^{\circ} 26^{\prime} 41^{\prime \prime}$ south latitude, $49^{\circ} 11^{\prime} 33^{\prime \prime}$ west longitude, at an altitude of $893 \mathrm{~m}$. The climate in the region is classified as humid subtropical of the $\mathrm{Cfb}$ type in the Köppen classification. The mean value of the hottest month is greater than $22{ }^{\circ} \mathrm{C}$, and of the coldest month, less than $18{ }^{\circ} \mathrm{C}$, without a dry season, and it has mild summer and severe and frequent frosts (IAPAR, 2011).

Cypselas (seed bearing fruit) of S. megapotamicum were placed to germinate in expanded polystyrene (EPS) sheets containing 128 cells of substrate fertilized with NPK in the proportion (13:2:13) in June 2010. After two months in a greenhouse, seedlings with approximately $5 \mathrm{~cm}$ of height were transplanted in black polyethylene bags $(10 \times 20 \mathrm{~cm}$, $700 \mathrm{~mL}$ capacity) in a substrate fertilized with NPK (13:2:13), remaining in the same environment.

Ninety-five plants were transplanted to previously plowed and disked soil, fertilized with $2.1 \mathrm{t} \mathrm{ha}^{-1}$ of limestone, at a spacing of $80 \times 80 \mathrm{~cm}$, supplying material for assessment of potential for landscaping use (60 plants) and post-harvest vase life (35 plants). Another one hundred plants were transplanted to four growing conditions, designed for the experiment of adaptability.

\section{Landscaping use}

With a view toward assessing the growth and development of the $S$. megapotamicum plants grown in a condition similar to that of a garden, the 60 plants were kept in full sun without irrigation until full flowering.

Measurements of plant height, diameter of the plants measured at $1 \mathrm{~m}$ height, number of secondary stems per plant, number of leaves per plant, diameter of the inflorescences, number of inflorescences per plant, flowering and fruit phenology, and number of cypselas per flower bud were evaluated 240 days after transplant.

\section{Cut flower use}

With a view toward assessing the ideal point for harvesting the stems and post-harvest longevity, $35 \mathrm{~S}$. megapotamicum plants were kept in full sun without irrigation. They supplied flower stems assessed in this experiment. After 210 days of growth in the field, flower stems with approximately $1 \mathrm{~m}$ length were collected from each plant. Flower buds in these stems showed different maturity and diameters ranged from 10 to $20 \mathrm{~mm}$. Flower buds were classified as class I, buds from 15 to $20 \mathrm{~mm}$, and class II, buds from 10 to $14 \mathrm{~mm}$. Stems were then placed in vases containing water and afterwards transported to the laboratory where this study was conducted. Stems were standardized to $70 \mathrm{~cm}$ length, defoliated at the basal $15 \mathrm{~cm}$ and immediately placed in vases with $1.0 \mathrm{~L}$ capacity with $600 \mathrm{~mL}$ of water. Every two days water was replenished, and environment temperature and humidity were daily monitored, remaining between 19 and $20^{\circ} \mathrm{C}$ and between 60 and $64 \%$ respectively. For the purpose of registering the post-harvest features, flower buds were measured with a caliper rule, and for eight days flower buds opening and bent neck incidence were observed.

Adaptability
One hundred $S$. megapotamicum plants were transplanted to four environmental conditions. Condition I was characterized as full sun and automated irrigation by means of a sprinkler with a discharge of $265 \mathrm{~L} \mathrm{~h}^{-1}$ (once at the end of the day). Condition II was under a shade screen (70\% shading) with manual daily irrigation. Condition III was in a greenhouse with an arch type roof covered with low density transparent polyethylene and closed at the sides under daily manual irrigation, and condition IV was full sun without irrigation. Experimental design in each growing condition was randomized blocks with five blocks and five plants per block. Throughout the entire period of research light intensity was daily measured with a luximeter.

Plants were grown under conditions I to IV during 240 days, at which time plant height, stem diameter, number of leaves per plant, plant fresh matter, plant dry matter, number of flower buds per plant and number of lateral stems per plant were measured. For determination of plant height, a metric tape measure was used, measuring the distance between soil and the plant apex. Plant diameter was measured considering the extremities of two opposing leaves that have the greatest dimension. Stem diameter was measured five centimeters above soil. A digital caliper rule was used for this purpose. Number of leaves was obtained by simple counting, discarding those less than $1 \mathrm{~cm}^{2}$.

For determination of fresh and dry matters an electronic analytical balance $(0,01 \mathrm{~g})$ was used. Leaf dry matter was obtained after drying in a forced air circulation laboratory oven at $65{ }^{\circ} \mathrm{C}$ for 48 hours. Number of flower buds per plant was evaluated through counting the buds of more than $5 \mathrm{~mm}$ diameter. Number of lateral branches was obtained by counting the shoots.

Results were submitted to analysis of variance and the mean values were compared by the Tukey test at $5 \%$ probability using the ASSISTAT computational program, version 7.6 beta (SILVA, 2008).

\section{RESULTS AND DISCUSSION}

\section{Landscaping use}

S. megapotamicum are annuals plants with height of $1.60 \mathrm{~m} \pm 0.4 \mathrm{~m}$ and diameter of $40 \mathrm{~cm} \pm 0.07 \mathrm{~m}$. They have on average six secondary stems per plant. Their leaves are hairy with a toothed edge, notable for their soft texture, containing $74.8 \pm 18$ leaves per plant. Inflorescences are capitulums with $15 \mathrm{~mm} \pm 5 \mathrm{~mm}$ diameter. Capitulums have hairy grayish bracts. Number of inflorescences per plant is $34.5 \pm 4.4$. Plants start flowering 120 days after transplant, in the first two weeks of March, bearing fruit in the month of May, with a dark brown fruit color. Each infructescence produces an average of 350 cypselas containing seeds. It was noted that plants had a strong smell, which possibly explains their high capacity for attracting bees, butterflies and small birds. Considering their esthetic characteristics, greater ornamental potential was observed in their inflorescences, similar to hairy pom-poms (Figure 1), very striking and colorful, which would probably make a beautiful landscaping effect. The delicacy of their numerous and dense inflorescences may fit very well in rock gardens, softening the presence of 
the stones. $S$. megapotamicum inflorescences may also be used in association with other native species that are in the process of extinction, such as bromeliads and various specimens of the Asteraceae family. This is in agreement with TABACOW (2004) who considers highly important to select plants aiming to create associations that appear like nature and give an appearance of spontaneity. $S$. megapotamicum branching lends volume may form groups or clumps, producing a tier effect, as recommended by LORENZI (2001) for use of diverse native plants.

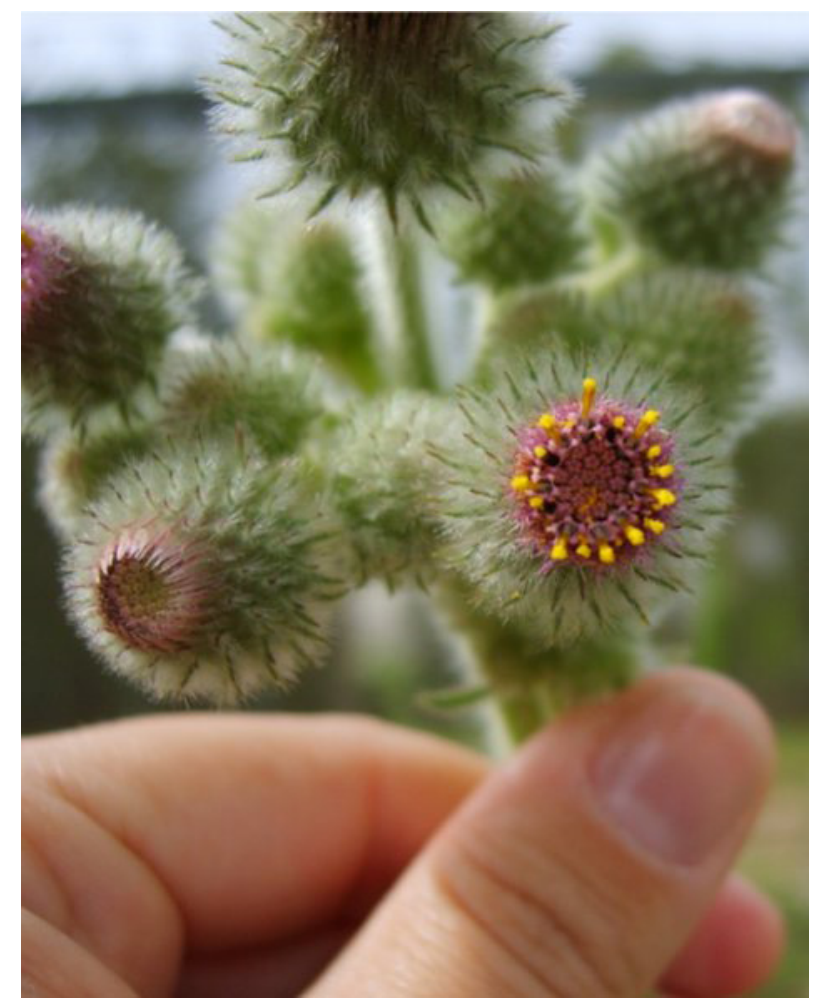

Figure 1. Stenachaenium megapotamicum inflorescenses

For commercial growing of this species as a potted plant, it is necessary to develop research for reducing its size. Considering growth in a $35 \mathrm{~cm}$ height pot and the IBRAFLOR (2000) recommendation that plant height should be from 1.5 to 2.3 times the height of the pot, the maximum height for potted growing is $80 \mathrm{~cm}$. It may be supposed that these plants will respond to a breeding process due to their heterogeneity in height $(1.2 \mathrm{~m}$ to $2.0 \mathrm{~m})$. Such heterogeneous size happened because this species has not yet been domesticated and genetically bred. This is in accordance with WALLACE et al. (2007) and JUNQUEIRA et al. (2010) who consider initial heterogeneity to be important for breeding purposes. In addition, the application of growth regulators may be favorable for reducing plant height, as observed by MATEUS et al. (2009) in sunflowers.

\section{Cut flower use}

Anthesis only happened in flower buds of more than 10 $\mathrm{mm}$ diameter. Flower vase life was $5.3 \pm 2.0$ days. Rate of opening of buds was $17 \%$ in buds of 15 to $20 \mathrm{~mm}$ and $93 \%$ in buds of 10 to $14 \mathrm{~mm}$, showing that the ideal stage for stem collection is with buds from 10 to $14 \mathrm{~mm}$ diameter. It is important to define the ideal flower developmental stage for stem harvest, as indicated by LOGES et al. (2005) and SILVA et al. (2008).

In regard to vase life, after seven days all stems showed bend neck; however, flower buds proved not to have loss of turgidity until the end of the study. According to WEISS (2002), a species without minimum durability of seven days in the consumers' home may not become a commercial species. Therefore, S. megapotamicum needs genetic breeding to increase its vase life.

In comparison with other Asteraceae grown commercially as cut flowers, such as chrysanthemum and aster, $S$. megapotamicum has some advantages. Its stems are naturally long $(1.60 \mathrm{~cm} \pm 0.4 \mathrm{~m})$, not needing to undergo the application of plant growth regulators (SCHMIDT et al., 2003). In addition, they do not undergo damping off, which is probably due to greater stem diameter $(2 \mathrm{~cm} \pm 1 \mathrm{~cm})$ and resistance, with the possibility of growing without the use of tutor, as is recommended for chrysanthemum by REGO et al. (2009). Big inflorescence size $(10 \mathrm{~cm} \pm 0.3 \mathrm{~cm})$, a lot branches per plant $( \pm 6)$, and a lot of inflorescences per branch are good features for cut flowers (STUMPF et al., 2008) indicating a possible use for $S$. megapotamicum.

\section{Adaptability}

During this study the average minimum temperature was $14.6{ }^{\circ} \mathrm{C}$ and the average maximum temperature was $24.4{ }^{\circ} \mathrm{C}$, total rainfall was $1,972.8 \mathrm{~mm}$, an average of 5.4 $\mathrm{mm}$ day $^{-1}$ (Figure 2). These temperatures are near to those that occur in Rio Grande do Sul State (KUINCHTNER\& BURIOL, 2001) where this species was also related spontaneously occurring by STUMPF et al. (2008). 

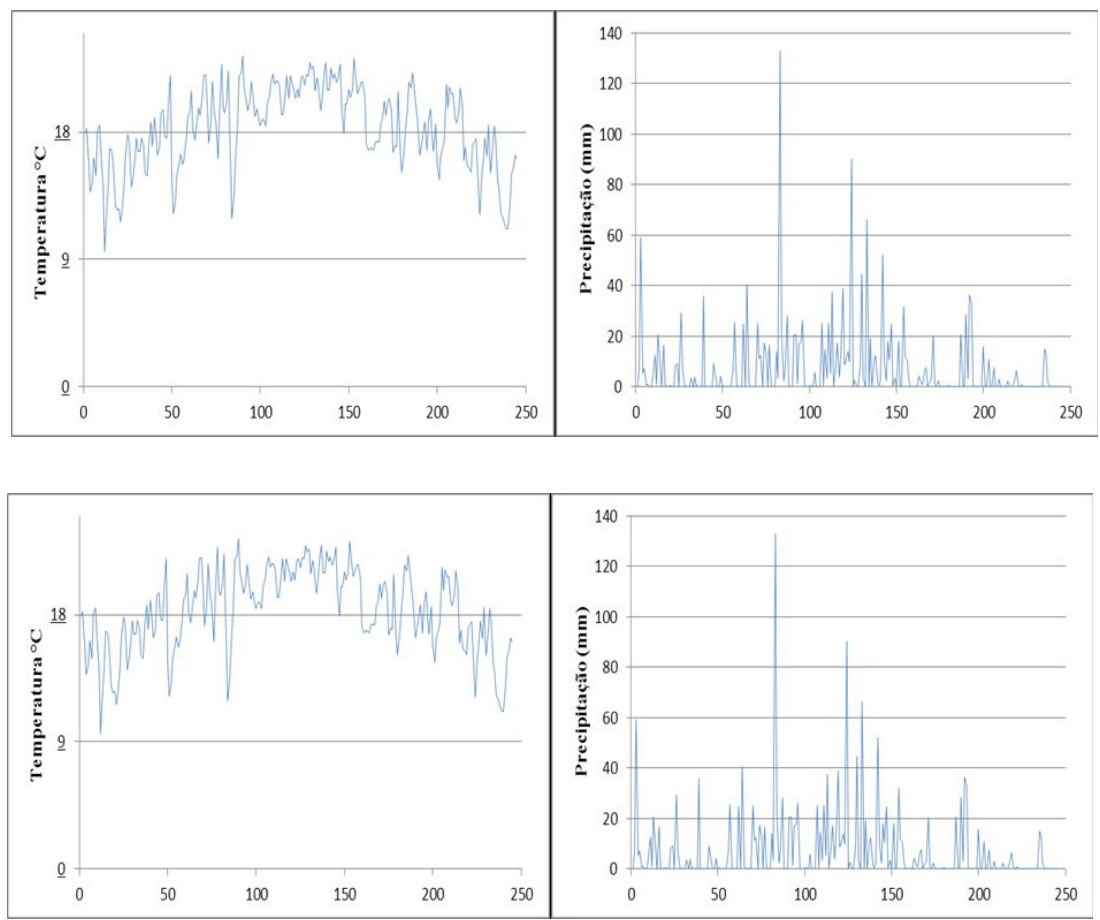

Figure 2. Air temperature $\left({ }^{\circ} \mathrm{C}\right)$ and rainfall $(\mathrm{mm})$ during 240 days of Stenachaenium megapotamicum growing, Pinhais, PR, Brazil

Results obtained showed that $S$. megapotamicum is a heliophile plant due to its good development under full sun with irrigation (Table 1). Height of plants grown in full sun with irrigation and under a shade screen with irrigation was similar. This similarity under different light condition might be due to lower luminosity (Table 2) under the shade screen, which caused plants etiolating. The capacity for growing rapidly in height when shaded proves to be an important adaptation mechanism which occurs with species that need to seek for greater light conditions (ZANELLA et al., 2006). Plant survival in full sun with irrigation and under shading was $100 \%$. Observing all the other variables, lower luminosity showed to be adverse to $S$. megapotamicum growth and development comparing with full sun with irrigation.

Plants grown inside a greenhouse had smaller stem diameter, smaller number of branches, smaller number of leaves, and less dry matter than plants grown under full sun with irrigation (Table 1), providing evidence of adverse physiological processes under this condition. In the same way, this growing condition also affected plant survival, which was $68 \%$. Probably, photosynthesis was limited by the lower luminosity (Table 2), in agreement with TAIZ and ZEIGER (2004), who cited the importance of light in plant metabolic processes.

Under full sun without irrigation, plants were shorter comparing with the other environments (Table 1). During the study period, there was low rainfall in some months (Figure 2), which may have damaged most physiological processes causing also the other effects observed in Table 1. This is in accordance with TAIZ and ZEIGER (2004) who note that water deficiency compromises most physiological processes. The survival rate was $44 \%$, and the plants did not produce fruits under this growing condition.

Although lower plants height may be more interesting for landscaping (BARBOSA et al., 2008), the smaller size of $S$. megapotamicum plants (Table 1) was generally associated with growing conditions where the other metabolic processes were much compromised. This shows the superiority of growing in full sun with irrigation. 
Table 1. Growth parameters of Stenachaenium megapotamicum grown under four growing conditions during 240 days, Pinhais, PR, Brazil

Table 1. Growth parameters of Stenachaenium megapotamicum grown under four growing conditions during 240 days, Pinhais, PR, Brazil

\begin{tabular}{lccccccc}
\hline Growing conditions & $\begin{array}{c}\text { Height } \\
(\mathrm{cm})\end{array}$ & $\begin{array}{c}\text { Stem } \\
\text { diameter } \\
(\mathrm{mm})\end{array}$ & $\begin{array}{c}\text { Branches } \\
\text { number }\end{array}$ & $\begin{array}{c}\text { Leaves } \\
\text { number }\end{array}$ & $\begin{array}{c}\text { Buds } \\
\text { number }\end{array}$ & $\begin{array}{c}\text { Fresh } \\
\text { matter (g) }\end{array}$ & $\begin{array}{c}\text { Dry } \\
\text { matter (g) }\end{array}$ \\
\hline $\begin{array}{l}\text { Full sun with } \\
\text { irrigation }\end{array}$ & $131.8 \mathrm{a}$ & $8.4 \mathrm{~b}$ & $5.3 \mathrm{a}$ & $56.3 \mathrm{a}$ & $32 \mathrm{a}$ & $180.5 \mathrm{a}$ & $44.9 \mathrm{a}$ \\
$\begin{array}{l}\text { Under shade screen } \\
\text { with irrigation }\end{array}$ & $136.2 \mathrm{a}$ & $5.8 \mathrm{c}$ & $2.0 \mathrm{~b}$ & $27.6 \mathrm{~b}$ & $19 \mathrm{~b}$ & $99.7 \mathrm{c}$ & $23.2 \mathrm{c}$ \\
$\begin{array}{l}\text { Greenhouse with } \\
\text { irrigation }\end{array}$ & $97.2 \mathrm{~b}$ & $6.0 \mathrm{c}$ & $1.2 \mathrm{~b}$ & $26.1 \mathrm{~b}$ & $5 \mathrm{c}$ & $165.3 \mathrm{a}$ & $30.9 \mathrm{~b}$ \\
$\begin{array}{l}\text { Full sun without } \\
\text { irrigation }\end{array}$ & $76.8 \mathrm{c}$ & $9.8 \mathrm{a}$ & $1.5 \mathrm{~b}$ & $41.6 \mathrm{ab}$ & $9 \mathrm{c}$ & $130.7 \mathrm{~b}$ & $24.6 \mathrm{c}$ \\
\hline C. V. (\%) & 11 & 12 & 29 & 15 & 21 & 13 & 14 \\
\hline
\end{tabular}

Means followed by the same small letter in the column do not differ by the Tukey Test at $5 \%$ probability

Table 2. Average luminosity for growing conditions of Stenachaenium megapotamicum during 240 days, Pinhais, PR, Brazil

Table 2. Average luminosity for growing conditions of Stenachaenium megapotamicum during 240 days, Pinhais, PR, Brazil

\begin{tabular}{lc}
\hline Growing conditions & Average luminosity (Lx) \\
\hline Full sun with irrigation & $497.93 \mathrm{a}$ \\
Under shade screen with irrigation & $393.87 \mathrm{~b}$ \\
Greenhouse with irrigation & $211.97 \mathrm{c}$ \\
Full sun without irrigation & $499.94 \mathrm{a}$ \\
\hline C. V. (\%) & $37 \%$ \\
\hline Meens followed by the same small letter in the column do not differ by the Tukey Test at $\%$ probability &
\end{tabular}

\section{CONCLUSION}

S. megapotamicum plants are adapted to growth in full sun with daily irrigation. They have potential for use as cut flower and in landscaping, although they are not recommended for use as potted plants due to their excessive height.

\section{REFERENCES}

BARBOSA, J. G. et al. Cultivo de girassol ornamental (Helianthus annuus L.) em vaso sob diferentes doses de paclobutrazol. Revista Brasileira de Horticultura Ornamental, v.14, n.2, p. 205-208, 2008.

BARROSO, C. M. et al. Considerações sobre a propagação e o uso ornamental de plantas raras ou ameaçadas de extinção no Rio Grande do Sul, Brasil. Revista Brasileira de Horticultura Ornamental, v.13, n.1, p.91-94, 2007.

CARDOSO, J. C. Laeliocattleya'Brazilian Girl Rosa': cultivar de orquídea para cultivo em vaso. Horticultura Brasileira, Brasília, v.28, n.3, 2010.

HEIDEN, G; BARBIERI, R. L.; STUMPF, E. R. T. Considerações sobre o uso de plantas ornamentais nativas. Revista Brasileira de Horticultura Ornamental, v.12, n.1, p.2-7, 2006.

IAPAR. Cartas climáticas do Paraná. Available at: $<$ http://www.iapar.br/modules/conteudo/conteudo. php? conteudo=863>. Accessed on: Nov. 17, 2011.

IBRAFLOR. Padrão Instituto Brasileiro de floricultura 
de qualidade. São Paulo: IBRAFLOR, 2000.

JUNQUEIRA, K. P.et al. Variabilidade genética de acessos de pitaya com diferentes níveis de produção por meio de marcadores RAPD. Revista Brasileira de Fruticultura, v.32, n.3, p.840-846, 2010.

KUINCHTNER, A.; BURIOL, G. A. Clima do Estado do Rio Grande do Sul segundo a classificação de Köppen e Thornthwaite. Disciplinarum Scientia, v.2, n.1, p.171182,2001

LOGES, V et al. Colheita, pós-colheita e embalagem de flores tropicais em Pernambuco. Horticultura Brasileira, v.23, n.3, p.699-702, 2005.

LORENZI, H. Plantas Ornamentais no Brasil: arbustivas, herbáceas e trepadeiras. 3. ed. Nova Odessa, SP: Instituto Plantarum, 2001.

MATEUS, C. M. D. et al. Estratégias para redução do porte de girassol ornamental para comercialização em vaso. Bragantia, v.68, n.3, p. 681-687, 2009.

OTTMANN, M. M. A. et al. Por que estudar a produção de plantas ornamentais? O caso Catarinense. Revista Brasileira de Horticultura Ornamental, v.14, n.1, p.8590, 2008.

REGO, J. de L et al. Produtividade de crisântemo em função de níveis de irrigação. Horticultura Brasileira, v.27, n.1, p.45-49, 2009.

SCHMIDT, C. $M$ et al. Ácido giberélico $\left(\mathrm{GA}_{3}\right)$ no crisântemo (Dedranthema grandifloraTzvelev.) de corte: cultivo de verão. Ciência Rural, v.33, p.267-274, 2003.

SILVA, F. de A. S. Sistema de Assistência Estatística Assistat versão $\mathbf{7 . 6}$ beta. Departamento de Engenharia Agrícola (DEAG) do CTRN da Universidade Federal de Campina Grande $\square$ UFCG. Campina Grande - PB, 2008.
Available at: $<$ http://www.assistat.com $>$.

SILVA, L. R. da; OLIVEIRA, M. D. de M.; SILVA, S. de M. Manejo pós-colheita de hastes florais de gladíolos (Gladiolusgrandiflorus L.) Acta Agronómica, v.57, n.2, p.129-135, 2008.

SOUZA, A. R. C. de et al. Consumo hídrico e desempenho de Kalanchoe cultivado em substratos alternativos. Ciência Rural, v.40, n.3, p.534-540, 2010.

STUMPF, E. R. T.; BARBIERI, R. L.; HEIDEN, G. Cores e formas no Bioma Pampa - plantas ornamentais nativas. Pelotas: Embrapa clima temperado, 2009. 276 p.

STUMPF, E. R. T et al. Prospecção de plantas nativas do Bioma Pampa para uso na arte floral. BioScriba, v.1, n.2, p.65-72, 2008.

TABACOW, J. Roberto Burle Marx - arte e paisagismo. 2 ed. São Paulo: Studio Nobel, 2004.

TAIZ, L.; ZEIGER, E. Fisiologia vegetal. 3. ed. Porto Alegre: Artmed, 2004. 722p.

WALLACE, R.; KREWER, G.; FONSAH, E. G. Ornamental Bananas: New hybrids from a group of underutilized landscape plants. Southeastern Palms, v.15, p.10-18, 2007.

WEISS, D. Introduction of new cut flowers; domestication of new species and introduction of new traits not found in commercial varieties. p. 129-137. In: VAINSTEIN, A. (Ed.). Breeding for ornamentals, Dordrecht: Springer, 2002, 450 p.

ZANELLA, F.; SONCELA, R.; LIMA, A. L. da S. Formação de mudas de maracujazeiro amarelo sob níveis de sombreamento em Ji-Paraná, RO. Ciência e Agrotecnologia, v.30, n. 5, p.880-884, 2006. 